\title{
DATING BEHAVIOUR AND ITS ASSOCIATED FACTORS AMONG FEMALE ADOLESCENTS IN INDONESIA: A SCHOOL-BASED SURVEY
}

\author{
Tirta Amerta Isworo1, Tantut Susanto², Dewi Rochmah ${ }^{3}$
}

1. Master of Public Health Program, School of Postgraduate Program, Universitas Jember

2. Department of Community, Family \& Geriatric Nursing, Faculty of Nursing, Universitas Jember

3. Department of Behavior and Health Promotion, Faculty of Public Health, Universitas Jember

\begin{abstract}
Sexuality and reproductive health are sensitive issues for families, schools and communities to discuss with adolescents in Indonesian social, cultural and religious context. This study aims to identify dating and its associated factors in female adolescents in Indonesia. This school-based survey was conducted among 577 students who completed a self-administered questionnaire that included socio-demographic information, discussion on reproductive health with parents, teachers and peers, and physical and psychological development. The results show that $56.5 \%(95 \% \mathrm{Cl}: 51.1 \%-61.8 \%)$ female adolescents had dating experience. Age $(\mathrm{OR}=1.63 ; 95 \% \mathrm{Cl}=1.13-2.35)$, lack of information on development $(\mathrm{OR}=$ $0.39 ; 95 \% \mathrm{Cl}=0.23-0.67)$, menstruation $(\mathrm{OR}=3.07) ; 95 \% \mathrm{Cl}=1.54-6.11)$, lack of discussion with teachers on the topics of puberty $(\mathrm{OR}=2.94 ; 95 \% \mathrm{Cl}=1.58-5.47)$ and dating $(\mathrm{OR}=1.53 ; 95 \% \mathrm{Cl}=1.03$ 2.28) are associated with dating behaviour. Characteristics of adolescents and discussion patterns between children and parents and teachers are also associated with dating behaviour. The results indicate that an integrated school-based sex education program that also involves parents is needed in the context of Indonesia.
\end{abstract}

Keywords: Dating, Adolescent, Parent, Teacher, Peer

\section{ABSTRAK}

Masalah sexualitas dan kesehatan reproduksi merupakan isu yang sensitif untuk didiskusikan diantara keluarga, sekolah, masyarakat dengan anak remaja dalam konteks sosial, budaya dan agama di Indonesia. Penelitian ini bertujuan untuk mengidentifikasi kejadian pacaran dan faktor yang mempengaruhinya pada remaja putri di Kabupaten Jember. Survei berbasis sekolah ini dilakukan pada 577 remaja putri melalui pengisian kuesioner oleh remaja terkait dengan karakteristik remaja, pola diskusi kesehatan reproduksi antara orang tua, guru, dan kelompok sebaya, serta perilaku pacaran dari remaja. Disamping itu juga dilakukan pengukuran terkait dengan perkembangan fisik dan psikologis remaja selama periode pubertas. Hasil menunjukkan perilaku berpacaran telah dilakukan oleh remaja sebesar $56.5 \%(95 \% \mathrm{Cl}$ : $51.1 \%-61.8 \%)$. Usia $(\mathrm{OR}=1.63 ; 95 \% \mathrm{Cl}=1.13-2.35)$, kurangnya akses informasi tentang perkembangan ( $\mathrm{OR}=0.39 ; 95 \% \mathrm{Cl}=0.23-0.67)$, menstruasi $(\mathrm{OR}=3.07) ; 95 \% \mathrm{Cl}=$ 1.54-6.11), tidak adanya diskusi terkait pubertas dengan guru $(\mathrm{OR}=2.94 ; 95 \% \mathrm{Cl}=1.58-5.47)$, dan tidak adanya diskusi terkait pacaran dengan guru $(\mathrm{OR}=1.53 ; 95 \% \mathrm{Cl}=1.03-2.28)$ merupakan faktor yang mempengaruhi perilaku pacarana remaja putri. Hasil ini mengindikasikan perlunya program pendidikan kesehatan reproduksi yang terintegrasi dengan sekolah termasuk adanya kelas diskusi bersama dengan orang tua di Indonesia.

Kata kunci: Pacaran, Remaja, Orang tua, Guru, Kelompok sebaya 


\section{INTRODUCTION}

A national survey on adolescents in Indonesia indicates that signs of premarital sexual behaviour have occurred in $5 \%$ of adolescents aged $10-24$ years (Ministry of Health Indonesia, 2013); more females $(40.6 \%)$ have shown negative adolescent reproductive health $(\mathrm{ARH})$ attitudes compared to males (37.1\%) (Susanto et al., 2016), whereas more males (56.6\%) have indicated active $\mathrm{ARH}$ behaviour compared to females (43.7\%) (Susanto, Rahmawati, Wuryaningsih, et al., 2016). These data indicate that the youth population in Indonesia is vulnerable and at risk of $\mathrm{ARH}$ problems, particularly relating to dating and masturbation behaviours. This can be prevented through the development of $\mathrm{ARH}$ programs to improve the communication between adolescents and their peers, parents and schools in the discussion of $\mathrm{ARH}$ issues.

Evidence has shown that sex education in schools can assist students as they navigate the physical and developmental processes of adolescent sexuality (Brewin, Koren, Morgan, Shipley, \& Hardy, 2014). Meanwhile, health promotion in schools can improve knowledge, attitude and skills of its students regarding clean and healthy living behaviour (Susanto, Sulistyorini, \& Wuryaningsih, 2016). On another note, parents and parenting behaviour also influence adolescent development (Schwartz et al., 2012). However, Indonesian parents still feel uncomfortable or afraid when discussing ARH issues with their adolescent children (Suwarni, Ismail, Prabandari, \& Adiyanti, 2015). Moreover, in its development, $A R H$ behaviour is strongly influenced by peers, both through descriptive norms (peer sexual behaviours) and injunctive norms (peer sexual attitudes), as well as peer pressure to have sex and adolescent sexual behaviour outcomes (sexual activity and sexual risk behaviour) (van de Bongardt, Reitz, Sandfort, \& Deković, 2015). This situation indicates that schools, parents, teachers and peers play an important role in affecting the discussion of $\mathrm{ARH}$ during puberty as well as the problems that may occur.
There has been limited research on how to approach a discussion on $\mathrm{ARH}$ between parents, teachers and peers regarding the risk factors and the negative aspects of dating and masturbation in Indonesia, considering that reproductive health and sexuality are often viewed as taboo in the social and cultural context (Susanto, Kimura, Rumiko, \& Tsuda, 2016). Adolescents in Indonesia possess a lower degree of knowledge, attitude, and skills on $A R H$, which means they need a program based on community and family (Tantut Susanto, Rahmawati, \& Wantiyah, 2016a), while they are also not focused on their future family planning (Susanto, Kimura, Tsuda, Wuryaningsih, \& Rahmawati, 2016). Therefore, reducing high-risk sexual behaviour may require a unique set of skills and experiences related to communication patterns between children, parents, peers and schools.

Furthermore, schools, parents and peers are the essential elements that influence $\mathrm{ARH}$. Communication through open discussion on ARH between adolescents, peers, parents and schools should be identified to achieve positive youth development. Healthcare workers, particularly in school nurses, can facilitate communication and reduce the gap between adolescents and their environment (peers, parents and schools) through $\mathrm{ARH}$ discussion topics to prevent risky ARH behaviour, such as dating and masturbation, particularly in the Indonesian social, cultural and religious context. Therefore, the purpose of this study was to examine the prevalence of dating and its associated factors among female adolescent in Jember District, East Java, Indonesia.

\section{METHOD}

A school-based cross-sectional survey was conducted in Jember District. We used a multiple-stage sampling method to recruit students for this survey. In the preliminary stage, we randomly selected an area, local sub-district and schools. In each school, we divided the students into three grades and then randomly selected some students from each grade. In each of the selected 
schools, 6 students were selected and 2 students were invited to participate from each grade. A total of 577 students (age 15-18 years) have completed the questionnaire. The eligibility criteria included: 1 ) students aged $11-19$ years; 2 ) students with consent from a parent or guardian after being explained the purpose, risk and benefits of the study; 3 ) students registered at the selected school; and, 4) having the ability to understand and respond to survey questions and agreeing to a physical assessment. This study was approved by the Ethical Committee Review Boards of Dental Faculty University of Jember East Java Indonesia No. 879/UN25.8/KEPK/DL/202 0 .

In the selected schools, the researchers met the teachers to get official approval. Then, the researchers divided the sample according to the three grades of class and then randomly selected 2 students from each grade who fulfilled the inclusion criteria. Informed consent was directly given to the students accompanied by their teachers and indirectly given to their parents at home through the signing of the informed consent sheet. If any students or parents refuse, other students would be selected until the random sample of six students at each school was obtained. The students who were selected will fill out the questionnaire of general questions independently. Then, the students would continue to answer specific questions asked directly by the researchers one by one in a closed room. After that, the students would continue on to the physical examination of their physical and psychological development. These research activities took approximately 30 minutes for each student. The completed questionnaires will then be carefully checked and will be included in the research analysis.

Research data were collected using a questionnaire adopted from the previous studies (Susanto, Rahmawati, Wuryaningsih, et al., 2016). The questionnaire consisted of 18 questions that were divided into three parts for a selfadministered questionnaire that investigated the socio-demographics, whether the adolescents have received information on $\mathrm{ARH}$ and development, whether they have ever talked about ARH with their parents, their sexual development physically and psychologically, whether they have ever discussed $\mathrm{ARH}$ (puberty, menstruation, dating, and masturbation) with parents, teachers and peers, as well as their dating behaviours.

Dating behaviour was assessed with the questions: "Have you ever dated before?" and "Have you ever masturbated before?" The responses to the questions were set as dichotomized answers (yes or no). Socio-demographic data include questions such as age, area (urban vs. rural), knowledge on reproductive health and development (no or yes), and discussion about $\mathrm{ARH}$ with their parents (often, occasionally or never). Physical and psychological changes in terms of sexual development experienced during puberty (Susanto et al., 2016) were assessed using ten items comprising of physical (6) and psychological (4) items with yes and no responses which was then calculated. Physical development consisted of signs of sexual maturation for females (growth of breasts; nipple changes; widened hips; hair growth in the genitalia and armpit; and oily skin). Psychological development consisted of increased attention to the opposite sex, having the desire to be considered as an adult, becoming more sensitive, and enjoying looking at the mirror. For the analysis, the responses were dichotomized as mature vs. immature (Susanto et al., 2018).

Descriptive statistics of frequencies was performed to identify the occurrence of dating. Then, a logistic regression analysis was used to examine associations between dating groups (yes or no) and discussion patterns between the children with their peers, parents, and teachers. A $p$ value of less than .05 was used to determine the statistical significance. All data was analysed using SPSS version 22.0.

\section{RESULT}

A total of 577 female adolescents participating in this study were between $17-18$ years $(59.4 \%)$, from rural areas 
$(68.8 \%)$ and have started menstruating $(91.5 \%)$, as described on Table 1.

Table 1. Characteristics of participants $(n=577)$

\begin{tabular}{lc}
\hline \multicolumn{1}{c}{ Variables } & $\mathbf{n}(\%)$ \\
\hline Age (year) & $234(40.6)$ \\
$15-16$ & $343(59.4)$ \\
$17-18$ & \\
Area & $397(68.8)$ \\
$\quad$ Rural & $180(31.2)$ \\
$\quad$ Urban & \\
Discussed RH with & \\
parents & $129(22.4)$ \\
$\quad$ Often & $332(57.5)$ \\
Occasionally & $116(20.1)$ \\
$\quad$ Never & \\
Have received information & \\
about development & \\
$\quad$ No & $95(16.5)$ \\
$\quad$ Yes & $482(83.5)$ \\
Have received information & \\
about ARH & \\
$\quad$ No & \\
$\quad$ Yes & $90(15.6)$ \\
Have started menstruating & $487(84.4)$ \\
$\quad$ No & $49(8.5)$ \\
$\quad$ Yes & $528(91.5)$ \\
Physical Development & \\
$\quad$ Immature & \\
$\quad$ Mature & $255(44.2)$ \\
Psychological & $322(55.8)$ \\
Development & \\
Immature & \\
Mature & \\
\hline &
\end{tabular}

Meanwhile, discussion on menstruation, masturbation, puberty and dating between adolescents and their peers, parents and teachers is described on Table 2. Respondents with dating experience made up a total of $56.5 \%(95 \%$ Cl: $51.1 \%-61.8 \%)$. Additionally, the occurrence of masturbation among the respondents is $6.6 \%(95 \% \mathrm{Cl}:-1.3 \%-$ $14.5 \%)$.

Table 2. Discussion patterns between adolescents and their parents, teachers, and peers relating to menstruation, masturbation, puberty and dating $(n=577)$

\begin{tabular}{|c|c|c|}
\hline Variables & Yes & No \\
\hline \multicolumn{3}{|c|}{ Discussion on menstruation } \\
\hline Parents & $454(78.7)$ & 1.3) \\
\hline Teachers & 138 & $6.1)$ \\
\hline Peers & $317(54.9)$ & $260(45.1)$ \\
\hline
\end{tabular}

Discussion on masturbation

$\begin{array}{lll}\text { Parents } & 401(69.5) & 176(30.5) \\ \text { Teachers } & 445(77.1) & 132(22.9) \\ \text { Peers } & 420(72.8) & 157(27.2) \\ \text { scussion on puberty } & \\ \text { Parents } & 464(80.4) & 113(19.6) \\ \text { Teachers } & 73(12.7) & 504(87.3) \\ \text { Peers } & 232(40.2) & 345(59.8)\end{array}$

Discussion on dating

\begin{tabular}{lll} 
Parents & $337(58.4)$ & $240(41.6)$ \\
Teachers & $400(69.3)$ & $177(30.7)$ \\
Peers & $282(48.9)$ & $295(51.1)$ \\
\hline
\end{tabular}

Chi square analysis was used to select candidate-related factors for the occurrence of dating among the respondents in multivariate analysis (Table 3). Then, we were evaluated candidate variable with $p$ less than 0.05 , including age, their discussion on $\mathrm{RH}$ with a parent, information received about development and $\mathrm{RH}$, and also menstruation.

Table 3. Dating behaviour according to the adolescents' characteristics ( $n=577)$.

\begin{tabular}{lccc} 
& \multicolumn{3}{c}{ Dating } \\
\cline { 2 - 4 } & $\begin{array}{c}\text { No } \\
\mathbf{n}(\%)\end{array}$ & $\begin{array}{c}\text { Yes } \\
\mathbf{n}(\%)\end{array}$ & $\mathbf{X}^{2}(\mathbf{P})$ \\
\hline Age (year) & $119(47.4)$ & $115(35.3)$ & $8.16(.004)$ \\
$15-16$ & $132(52.6)$ & $211(64.7)$ & \\
$17-18$ & $169(67.3)$ & $228(69.9)$ & $0.34(.562)$ \\
Area & $82(32.7)$ & $98(30.1)$ & \\
$\quad$ Rural & $56(22.3)$ & $73(22.4)$ & $7.41(.025)$ \\
$\quad$ Urban & $132(52.6)$ & $200(61.3)$ & \\
$\begin{array}{l}\text { Discussed RH with parents } \\
\text { Often }\end{array}$ & $63(25.1)$ & $53(16.3)$ & \\
$\quad$ Occasionally & & & \\
$\quad$ Never & $22(8.8)$ & $73(22.4)$ & $18.17(<.001)$ \\
Have received information & & & \\
about development & & & \\
$\quad$ No & & &
\end{tabular}




\begin{tabular}{|c|c|c|c|}
\hline \multirow[b]{2}{*}{ Variables } & \multicolumn{3}{|c|}{ Dating } \\
\hline & $\begin{array}{c}\text { No } \\
\text { n (\%) }\end{array}$ & $\begin{array}{c}\text { Yes } \\
\text { n (\%) }\end{array}$ & $\mathrm{X}^{2}(\mathrm{P})$ \\
\hline Yes & $229(91.2)$ & $253(77.6)$ & \\
\hline $\begin{array}{l}\text { Have received information } \\
\text { about } R H\end{array}$ & & & \\
\hline No & $24(9.6)$ & $66(20.2)$ & $11.50(.001)$ \\
\hline Yes & $227(90.4)$ & $260(79.8)$ & \\
\hline Have started menstruating & & & \\
\hline No & 35 (13.9) & $14(4.3)$ & $15.77(<.001)$ \\
\hline Yes & $216(86.1)$ & $312(95.7)$ & \\
\hline Physical Development & & & \\
\hline Immature & $122(48.6)$ & $133(40.8)$ & $3.20(.074)$ \\
\hline Mature & $129(51.4)$ & $193(59.2)$ & \\
\hline Psychological Development & & & \\
\hline Immature & $69(27.5)$ & $79(24.2)$ & $0.63(.428)$ \\
\hline Mature & $182(72.5)$ & $247(75.8)$ & \\
\hline
\end{tabular}

Note. $\mathrm{RH}=$ reproductive health. $\mathrm{p}$ values determined by Chi square $\mathrm{x} 2$

Chi square analysis was used to select candidate-related factors for the occurrence of dating among female adolescents in multivariate analysis (Table 4). Then, we were evaluated candidate variable with $p$ less than 0.05 , including discussing around $\mathrm{RH}$ issues (including menstruation, masturbation, puberty, dating) with peers, parents, and teachers.

Table 4. Dating behaviour according to discussion patterns between parents, schools, peers and adolescents $(n=577)$.

\begin{tabular}{|c|c|c|c|c|}
\hline \multirow{2}{*}{ Variables } & & \multicolumn{3}{|c|}{ Experienced Dating } \\
\hline & & $\begin{array}{c}\text { No } \\
n(\%)\end{array}$ & $\begin{array}{c}\text { Yes } \\
\mathrm{n}(\%)\end{array}$ & $\mathrm{x}^{2}(\mathrm{P})$ \\
\hline \multicolumn{5}{|l|}{ Discussion on menstruation } \\
\hline \multirow[t]{2}{*}{ Parents } & No & $61(24.3)$ & $62(19.0)$ & $2.06(.152)$ \\
\hline & Yes & $190(75.7)$ & $264(81.0)$ & \\
\hline \multirow[t]{2}{*}{ Teachers } & No & $201(80.1)$ & $238(73.0)$ & $3.52(.061)$ \\
\hline & Yes & $50(19.9)$ & $88(27.0)$ & \\
\hline \multirow[t]{2}{*}{ Peers } & No & $133(53.0)$ & $127(39.0)$ & $10.72(.001)$ \\
\hline & Yes & $118(47.0)$ & $199(61.0)$ & \\
\hline \multicolumn{5}{|l|}{ Discussion on masturbation } \\
\hline \multirow[t]{2}{*}{ Parents } & Yes & $188(74.9)$ & $213(65.3)$ & $5.67(.017)$ \\
\hline & No & $63(25.1)$ & $113(34.7)$ & \\
\hline \multirow[t]{2}{*}{ Teachers } & Yes & 209 (83.3) & $236(72.4)$ & $8.90(.003)$ \\
\hline & No & $42(16.7)$ & $90(27.6)$ & \\
\hline \multirow[t]{2}{*}{ Peers } & Yes & $193(76.9)$ & $227(69.6)$ & $3.42(.065)$ \\
\hline & No & $58(23.1)$ & $99(30.4)$ & \\
\hline \multicolumn{5}{|l|}{ Discussion on puberty } \\
\hline \multirow[t]{2}{*}{ Parents } & No & $56(22.3)$ & $57(17.5)$ & $1.80(.179)$ \\
\hline & Yes & $195(77.7)$ & $269(82.5)$ & \\
\hline \multirow[t]{2}{*}{ Teachers } & No & $236(94.0)$ & $268(82.2)$ & $16.86(<.001)$ \\
\hline & Yes & $15(6.0)$ & $58(17.8)$ & \\
\hline \multirow[t]{2}{*}{ Peers } & No & $165(65.7)$ & $180(55.2)$ & $6.10(.014)$ \\
\hline & Yes & $86(34.3)$ & $146(44.8)$ & \\
\hline \multicolumn{5}{|l|}{ Discussion on dating } \\
\hline \multirow[t]{2}{*}{ Parents } & Yes & $161(64.1)$ & $176(54.0)$ & $5.61(.018)$ \\
\hline & No & $90(35.9)$ & $150(46.0)$ & \\
\hline \multirow[t]{2}{*}{ Teachers } & Yes & $193(76.9)$ & $207(63.5)$ & $11.34(.001)$ \\
\hline & No & $58(23.1)$ & $119(36.5)$ & \\
\hline \multirow[t]{2}{*}{ Peers } & Yes & $130(51.8)$ & $152(46.6)$ & $1.32(.251)$ \\
\hline & No & $121(48.2)$ & $174(53.4)$ & \\
\hline
\end{tabular}

Note. $\mathrm{p}$ values determined by Chi square $\mathrm{x} 2$ 
From a logistic regression analysis' (Table 5) point of view, the factors associated to the occurrence of dating among female adolescents are age (1416 years) OR 1.63 (95\% Cl: 1.13-2.35), having received information on development (yes) OR $0.39 \quad(95 \% \quad \mathrm{Cl}$ : 0.23-0.67), having started menstruating (yes) OR 3.07 (95\% Cl: 1.54-6.11), having discussed puberty with teachers (no) OR 2.94 (95\% Cl: 1.58-5.47) and discussed dating with teachers (no) OR 1.53 (95\% Cl: 1.03-2.28).

Table 5. Logistic regression analysis of factors associated with dating among female Adolescents $(n=577)$.

\begin{tabular}{|c|c|c|}
\hline \multirow[b]{2}{*}{ Variables } & \multicolumn{2}{|r|}{ Dating } \\
\hline & OR & $\begin{array}{c}95 \% \mathrm{Cl} \\
\text { (min-max) }\end{array}$ \\
\hline \multicolumn{3}{|l|}{ Age } \\
\hline $15-16$ years & & \\
\hline $17-18$ years & $1.63^{\star \star}$ & {$[1.13,2.35]$} \\
\hline \multicolumn{3}{|c|}{ Received information about development } \\
\hline No & Ref & {$[0.23,0.67]$} \\
\hline Yes & $0.39^{\star *}$ & \\
\hline \multirow{2}{*}{\multicolumn{3}{|c|}{$\begin{array}{l}\text { Started } \\
\text { menstruating }\end{array}$}} \\
\hline & & \\
\hline & & \\
\hline Yes & $3,07^{\star *}$ & {$[1.54,6.11]$} \\
\hline \multicolumn{3}{|c|}{ Discussed puberty with teachers } \\
\hline No & $2.94^{\star *}$ & {$[1.58,5.47]$} \\
\hline Yes & Ref & \\
\hline \multicolumn{3}{|c|}{ Discussed dating with teachers } \\
\hline No & $1.53^{\star *}$ & {$[1.03,2.28]$} \\
\hline Yes & Ref & \\
\hline \multicolumn{3}{|c|}{$\begin{array}{l}\text { Note. } \\
{ }^{*} \mathrm{p}<.05 .{ }^{* *} \mathrm{p}<.01{ }^{* * *} \mathrm{p}<.001 . \mathrm{OR}=\text { odds ratio } \\
\mathrm{Cl}=\text { confidence interval } \\
\text { The reference group in this analysis was } \mathrm{n} \\
\text { dating and no masturbation } \\
\text { For dating }=-2 \mathrm{LL} \mathrm{X}^{2}=727.100(p<.001) ; \text { Co } \\
\text { and Snell } \mathrm{R}^{2}=.103 ; \text { Nagelkerke } \mathrm{R}^{2}=.139 .\end{array}$} \\
\hline
\end{tabular}

\section{DISCUSSION}

\section{Dating among female adolescents}

This study found that $56.5 \%$ of the respondents have dating experience. This number is lower compared to a previous study where $67.4 \%$ of adolescents in Surabaya have been reported to have dating experience (Nur, Yumni, Minarti, \& Susanto, 2017). This difference may at least partially reflect differences in the characteristics of areas, whether participants live in rural or urban areas. The ARH behaviour and social aspects among rural and urban areas are different as confirmed in a previous study (Susanto, Rahmawati, \& Wantiyah, 2016). However, it is likely to increase in association with modernization (Susanto et al., 2016), leading to more access to information on $\mathrm{RH}$ in Indonesia (Bauer, 2015). Thus, our findings suggest the importance of healthpromotion strategies targeted to youth to prevent dating violence in Indonesia.

\section{Factors associated with dating among female adolescents}

Five factors were found to be related to female adolescents' dating behaviour: age, received information about development, menstruation, discussion of puberty with teachers, and discussion of dating with teachers. In this study, age is related to dating behaviour, which is consistent with a previous study in the US (Niolon et al., 2015). This finding may be explained by age maturation and sex hormones which simultaneously accelerate the physical and social maturation of adolescents. Therefore, attention should be given to adolescents during their development stage by their family to prevent negative dating behaviours.

Results showed that receiving information about development is related to dating behaviour. This finding is consistent with a previous study arguing that sources of information (Nobelius et al., 2010) are associated with $\mathrm{RH}$ behaviour. This may be explained by adolescents being in need of information on the physical, psychological, and emotional phases of growth and development in order to adapt to the changes during puberty. These results emphasize the importance of providing sources of correct information and promoting knowledge and understanding of ARH issues among adolescents (Susanto, Rahmawati, \& Wantiyah, 2018) to encourage positive attitudes regarding dating behaviours.

This study also found that menstruation is related to dating behaviour, which is similar to a previous study in Taiwan (Liu, Chen, \& Peng, 2012). This indicates that adolescents during menstrual periods tend to be very 
unstable and engage in risky behaviour such as dating; research on cultural practices during menstruation found that adolescents need support due to changes in their physiological and psychological conditions (Liu et al., 2012). Therefore, the role of teachers and schools during adolescent menstrual periods is important to avoid risky behaviour, although this is generally a time when teenagers begin dating (after they start menstruating).

In this study, the lack of discussion on puberty between adolescents and their teachers was related to dating behaviour. This may be explained by the fact that early puberty carries a greater number of risk behaviours compared to on-time or late puberty (Tsai, Strong, \& Lin, 2015). Moreover, we found that the lack of discussion between adolescents and teachers in regards to dating in female adolescents is similar to a previous study that found discussion and communication between adolescents and schools can improve ARH in Uganda (Muhwezi et al., 2015). Therefore, discussions of sex and dating with adolescents were perceived as the main source of information on sexuality. Schools could implement school health programs incorporating $\mathrm{ARH}$ curricula in the Indonesian context to reduce dating among adolescents.

The strength of the present study were identified the discussion between adolescents, peers, parents, teachers and the primary studies focused on third parties of children, family and school. During puberty, female adolescents need attention from their parents and teachers to monitor their ARH development due to their new experience in dating. In addition, some factors that influence dating and masturbation among female adolescents in this study are identified as the characteristics of adolescents. Unique findings showed that discussion with parents and teachers about puberty and masturbation have influenced their dating behaviour. Therefore, developing schoolbased health programs should be considered to reduce such voids in the discussions on topics that are important to their transition into adolescence. The programs may include parenting information for parents and ARH content in the school curriculum. The study results indicate that programs designed to promote $\mathrm{ARH}$ for female students must be tailored to their specific needs while paying attention to the social, cultural, and religious context.

However, this study has some limitations, including the cross-sectional nature of the study design, which resulted in associations found among the variables, rather than causal conclusions. Furthermore, there is a limitation regarding the measured pattern of discussion between adolescents, peers, parents, and teachers that may be different based on the social, cultural, and religion context. Therefore, further multicultural studies should be done to identify the patterns of discussion topics among female adolescents.

\section{CONCLUSION AND RECOMMENDA TION}

This study found that age, receiving information about development, menstruation, discussions on puberty with teachers, and discussions on dating with teachers were factors associated with dating behaviours. Thus, the study results suggest that sex education content focusing on communication patterns between adolescents and their peers, parents, and teachers should be included in health-promotion programs on sexuality and $A R H$ in school setting areas.

\section{REFERENCES}

Bauer, S. (2015). The association of sociodemographic, behavioural and informational factors with engaging in sexual intercourse among nevermarried adolescents aged $15-24$ years in Indonesia: A secondary analysis of DHS data from 2012. Uppsala Universitet. Thesis. Acsess from http://www.diva-portal.org/smas $\mathrm{h} /$ record.jsf?pid=diva2:819403.

Brewin, D., Koren, A., Morgan, B., Shipley, S., \& Hardy, R. L. (2014). Behind Closed Doors: School Nurses and Sexual Education. The Journal of School Nursing, 30(1), 31-41. https://doi.org/10.1177/10598405134 84363 
Liu, H. L., Chen, K. H., \& Peng, N. H. (2012). Cultural Practices Relating to Menarche and Menstruation among Adolescent Girls in TaiwanQualitative Investigation. Journal of Pediatric and Adolescent Gynecology, 25(1), 43-47. https://do i.org/10.1016/j.jpag.2011.08.006

Ministry of Health Indonesia. (2013). Riset kesehatan dasar. Riset Kesehatan Dasar 2013 (Basic Health research 2013). Jakarta.

Muhwezi, W. W., Katahoire, A. R., Banura, C., Mugooda, H., Kwesiga, D., Bastien, S., \& Klepp, K.-I. (2015). Perceptions and experiences of adolescents, parents and school administrators regarding adolescentparent communication on sexual and reproductive health issues in urban and rural Uganda. Reproductive Health, 12(1), 110. https://doi.org/ 10.1186/s12978-015-0099-3

Niolon, P. H., Vivolo-Kantor, A. M., Latzman, N. E., Valle, L. A., Kuoh, H., Burton, T., ... Tharp, A. T. (2015). Prevalence of Teen Dating Violence and Co-occurring Risk Factors Among Middle School Youth in High-Risk Urban Communities. Journal of Adolescent Health, 56(2), S5-S13. https://doi.org/10.1016/j.jad ohealth.2014.07.019

Nobelius, A.-M., Kalina, B., Pool, R., Whitworth, J., Chesters, J., \& Power, R. (2010). Sexual and reproductive health information sources preferred by out-of-school adolescents in rural southwest Uganda. Sex Education, 10(1), 91-107. https://doi.org/10.10 80/14681810903491438

Nur, S., Yumni, H., Minarti, \& Susanto, T. (2017). Structural model of factors relating to the health promotion behavior of reproductive health among Indonesian adolescents. International Journal of Nursing Sciences, 4(4), 367-373. https://doi. org/10.1016/j.jijnss.2017.10.001
Schwartz, O. S., Dudgeon, P., Sheeber, L. B., Yap, M. B. H., Simmons, J. G., \& Allen, N. B. (2012). Parental behaviors during family interactions predict changes in depression and anxiety symptoms during adolescence. Journal of Abnormal Child Psychology, 40(1), 59-71. https://doi.org/10.1007/s10802-0119542-2

Susanto, T., Rahmawati, I., Wuryaningsih, E. W., Saito, R., Syahrul, Kimura, R., ... Sugama, J. (2016). Prevalence of factors related to active reproductive health behavior: a cross-sectional study Indonesian adolescent. Epidemiology and Health, 38.

Susanto, T., Kimura, R., \& Tsuda, A. (2016). Risk Factors of Adolescent Sexual and Reproductive Health Behavior: A cross-sectional survey in an Islamic Culture of Indonesia. Journal of International Health, 31(3), 194 . https://doi.org/ 10.4178/epih.e2016041

Susanto, T., Kimura, R., Tsuda, A., Wuryaningsih, E. W., \& Rahmawati, I. (2016). Perception of adolescent for family planning at rural and urban area of East Java Province, Indonesia [Persepsi remaja dalam perencanaan keluarga di daerah rural dan urban kabupaten Jember, provinsi Jawa Timur, Indonesia: in Bahasa Indonesia]. Jurnal Keluarga Berencana (KB), 1(1), 1-10.

Susanto, T., Rahmawati, I., \& Wantiyah. (2016). A community-based friendly health clinic: An initiative adolescent reproductive health project in the rural and urban areas of Indonesia. International Journal of Nursing Sciences, 3(4), 371-378. https://doi.org/10.1016/j.jinss.2016.1 1.006

Susanto, T., Rahmawati, I., \& Wantiyah. (2018). Peer educator training program for enchancing knowledge on issues in the growth and development of adolescents and risk 
behavior problems in Indonesian context. Frontiers of Nursing, 5(3), 185-191.

Susanto, T., Rahmawati, I., Wuryaningsih, E. W., Saito, R., Kimura, R., Tsuda, A., ...Sugama, J. (2016). Prevalence of factors related to active reproductive health behavior: a cross-sectional study Indonesian adolescent. Epidemiology and Health, 38(e2016041), 1-10. https://doi.org/10.4178/epih.e201604 1

Susanto, T., Saito, R., Syahrul, Kimura, R., Tsuda, A., Tabuchi, N., \& Sugama, J. (2018). Immaturity in puberty and negative attitudes toward reproductive health among Indonesian adolescents. International Journal Adolescent Medicine and Health, 30(3). https://doi.org/10.1515/ijamh-20160051

Susanto, T., Sulistyorini, L., \& Wuri, E. (2016). A cross-sectional study on Clean and Healthy Living Program Behavior (CHLB) among Islamic Boarding Schools in Indonesia. International Journal of Nursing Sciences, 3(3), 291-298. https://doi.org/10.1016/j.jpnss.2016.0 8.007

Suwarni, L., Ismail, D., Prabandari, Y. S., \& Adiyanti, M. (2015). Perceived Parental Monitoring on Adolescence Premarital Sexual Behavior in Pontianak City, Indonesia. International Journal of Public Health Science, 4(3), 211-219. https://doi.org/ 10.11591/.v4i3.4736

Tsai, M.-C., Strong, C., \& Lin, C.-Y. (2015). Effects of pubertal timing on deviant behaviors in Taiwan: A longitudinal analysis of 7 th- to 12th-grade adolescents. Journal of Adolescence, 42(2), 87-97. https://doi.org/10.1016/j.adolescence .2015.03.016

van de Bongardt, D., Reitz, E., Sandfort, T., \& Deković, M. (2015). A MetaAnalysis of the Relations Between Three Types of Peer Norms and Adolescent Sexual Behavior. Personality and Social Psychology Review, 19(3), 203-234. https://doi.org/10.1177/10888683145 44223 